\title{
Improvement of People's Participation in Absorption Village Fund Allocation (Adg) For Poverty Reductionin The District Of Aceh
}

\author{
Sufitrayati $^{1}$, Fanny Nailufar ${ }^{2}$, Aliasuddin $^{3}$ and T. Zulham ${ }^{3}$ \\ \{ sufitrayati@,serambimekkah.ac.id,, fannynailufar@serambimekkah.ac.id\}
}

${ }^{1}$ Lecturer of Accounting Study Program Faculty of Economics, Serambi Mekkah University

${ }^{2}$ Lecturer of Management Studies Program Faculty of Economics, Serambi Mekkah University

${ }^{3}$ Lecturer of Development Economics Program Faculty of Economics and Business, Syiah Kuala

University

\begin{abstract}
This research has a purpose, namely; (1). To describe the results to be achieved in the role of community participation to improve the absorption of funds allocation in poverty alleviation village in Aceh Besar district, (2). To describe the implementation of increased community participation to improve the absorption of the Village Fund Allocation (ADG) in Aceh Besar district. In this research, using qualitative descriptive analysis method. The research data consist of primary data through interviews with respondents, community and village as well as using a list of questions prepared in advance and secondary data obtained from the Central Statistics Agency (BPS) and some lembagadi Aceh Besar. The results showed that the absorption of the Village Fund Allocation in Aceh Besar regency very varied. Determination of ADG in Aceh Besar district each year has increased. Generally the village fund allocation is allocated or its use is more widely used for village officials or usually called wage jerih.Dalam direct community participation is only a small part is involved, since generally all people are not involved, even people do not know and do not understand the use of allocation village funds. It is therefore expected of local governments is expected to arrange qanuns more flexible and not raw.
\end{abstract}

Keywords ; Participation, Absorption, the Village Fund Allocation, Poverty, district

\section{Introduction}

In the context of poverty reduction, various poverty alleviation programs that have been announced by the government has done with various programs on offer. It is not yet effective also poverty alleviation programs are implemented by the government can be seen from the human development index or the Human Development Index (HDI) Indonesia is relatively low, the poverty rate in Indonesia is still high, inequality of poverty is very large, and the area (village down-town) as well as between the islands. Based on BPS data (several years of publication) the majority of poor people in Indonesia, many accumulate in rural areas. Particularly in rural areas is not enough just to divide up the funds, because poverty was 
associated with lower welfare. Support the implementation of these activities as to which terdadapat in Aceh Besar Regent Regulation No. 3 of 2018 (PP 03/2018), which is necessary to allocate funds to the village in the form of village funds aloksi (ADG), which is an equalization fund and is expected to be the main buffer in the implementation of development and implementation of village communities, so as to improve the welfare of the village community.

\section{Methodology}

The study sample consisted of three (3) parts of a region with a large amount of ADG, medium and small. This study uses qualitative descriptive analysis. The research data consist of primary data and secondary data. Primary data will be obtained through interviews, questionnaires and observations. Interviews and questionnaires carried out to the community and the village associated tailored to the objectives to be achieved in this study.

\subsection{Society participation}

Participation comes from the English language is "participation" is taking partor inclusion. According to Keith Davis, participation is a person's mental and emotional involvement to the achievement of the goals and share responsibility in it. In the definition of the key idea is the mental and emotional involvement. In the opinion of Mubyarto (2015: 35) that defines participation as a willingness to help the success of any program in accordance with the ability of every person without means sacrificing self-interest. While the increase relating to the participation of the general public to do with training, education and stimulation of sustainable activities.

\subsection{The Village Fund Allocation (ADG)}

Policy Fund Allocation Gampong (ADG), which is set in the Regional Regulation No. 7 of 2016 on Guidelines for Finance of the District Government to the Government of the Village, that the finances of the village should be managed in an effective, efficient, economical, transparent and accountable with regard to the principle of compliance and benefits for community. Fund for Local Tax Revenue and the Regional retributions of funds allocated by the district for the village that comes from the funds of Tax District and regional retributions received by the District. Thus, the Village Fund Allocation (ADG) is a fund allocated by the local government for the Village, which is sourced from the financial equalization funds received by the district and the Village.

\subsection{Poverty}

This inability condition characterized by low ability of income to meet basic needs in the form of food, clothing, as well as the board. This low revenue capacity will also impact decreasing ability to meet the standards of the average life such as public health standards and educational standards. People called poor condition can be determined by the ability of income to meet living standards [1].

In principle, the standard of living in a society not merely insufficient need for food, but also insufficient demand for health and education. Residence or adequate housing is one of the standard of living or public welfare standards in an area. Under these circumstances, a society called poor if it has a much lower income than the average income,

so that not many have the opportunity to prosper himself (Suryawati, 2014). 


\section{Result and Discussion}

\subsection{Overview of Aceh Besar Geographically}

Aceh Besar district consists of 23 districts, Mukim 68, and 604 Gampong / village. The distance between the centers of districts and district centers vary greatly. Lhoong sub-district is the most distant regions, namely within $106 \mathrm{~km}$ with the center of the capital district located in the district town of Jantho.

\subsection{Absorption Gampong Allocation Fund (ADG) In Aceh Besar district}

The absorption of the Village Fund Allocation in Aceh Besar regency very varied. The research location is in addition to dividing the territory into three (3) parts, namely the West, Central Region / East and Northern Territory and also dividing the territory based on the amount the amount of ADG received. Therefore, the study sample was also divided into three (3) parts of a region with a large amount of ADG, medium and small. Following the division of the region can be seen in table 4.1

Table .1 Distribution of the District Location Based Research Number of ADG group in Aceh Besar district Year 2017

\begin{tabular}{|c|c|c|c|c|c|c|}
\hline \multirow[t]{2}{*}{ Area } & \multicolumn{2}{|c|}{$\begin{array}{c}\text { Group of Big } \\
\text { Budget }\end{array}$} & \multicolumn{2}{|c|}{$\begin{array}{c}\text { Group of Sedang } \\
\text { Budget }\end{array}$} & \multicolumn{2}{|c|}{$\begin{array}{c}\text { Group of Small } \\
\text { Budget }\end{array}$} \\
\hline & $\begin{array}{c}\text { Sub- } \\
\text { district }\end{array}$ & Total ADG & $\begin{array}{c}\text { Sub- } \\
\text { district }\end{array}$ & Total ADG & $\begin{array}{c}\text { Sub- } \\
\text { district }\end{array}$ & Total ADG \\
\hline West & $\begin{array}{l}\text { Darul } \\
\text { Imarah }\end{array}$ & 2.050 .751 .000 & $\begin{array}{l}\text { Peukan } \\
\text { Bada }\end{array}$ & 1.548 .217 .000 & $\begin{array}{l}\text { Darul } \\
\text { Kamal }\end{array}$ & 820.598 .000 \\
\hline $\begin{array}{l}\text { Centra } \\
\text { 1/ East }\end{array}$ & Indrapuri & 2.980 .357 .000 & $\begin{array}{l}\text { Simpang } \\
\text { Tiga }\end{array}$ & 1.002 .705 .000 & $\begin{array}{l}\text { Kuta } \\
\text { Malaka }\end{array}$ & 870.004 .000 \\
\hline North & Kuta Baro & 2.717 .952 .000 & Darussalam & 1.726 .468 .000 & Baitussalam & 841.912 .000 \\
\hline
\end{tabular}

Source: Central Statistics Agency (BPS) of Aceh in 2018 (processed)

In accordance with Table 4.1 above can be seen that every district in Aceh Besar district get a different amount of funds in the Village Fund Allocation (ADG). As we know that ADG comes from 10\% of General Allocation Fund (DAU) of Aceh Besar district which was then supplemented with $10 \%$ of the taxes and retributions Regions. The use of village funds received by the Government Gampong used for fixed income and Apparatus Keuchik Gampong. Funds are also used to support village Keuchik, Apparatus Gampong, Tuha Peut gampung Gampong and others. Gampong funds are also used as an aid orphans and underprivileged families transport rice and other expenditures that increase human capacity within the village in order to support the implementation of the village administration for Rp.3.000.000, - and for operational costs 2 wheel vehicles keuchik 1,000,000 -selanjutnya if there are remaining funds from the whole village funds will be used for other operational cost keuchik office. Thus the amount of ADG are funded by taxes and local retribution village received by the division of $60 \%$ for producers and $40 \%$ of the village is divided evenly to all of the village. So the village ADG reception producer according to the composition of tax revenue and local retribution 


\subsection{Public Participation To Increase Allocation Funds Absorption Gampong (ADG) In Aceh Besar district}

The participation of one of the elements of society development is a process of adaptation to the change underway. Based on the information obtained in the field, the study sought to obtain in-depth information regarding the level of participation of people who have been involved to attempt ADG absorption so that it can feed that effective impact on poverty. The information was obtained from the sampling of communities based on the number of households for each sub-district. The following data is based on the number of households District in Aceh Besar in Table .2

Table .2 Total KK Based Selection researched sub district in Aceh Besar district Year 2017

\begin{tabular}{lc} 
sub-district & Total KK \\
\hline Darul Imarah & 11378 \\
Peukan Bada & 4,471 \\
Darul Kamal & 1,747 \\
Indrapuri & 5089 \\
Simpang Tiga & 1,360 \\
Kuta Malaka & 1,398 \\
Kuta Baro & 5849 \\
Darussalam & 5686 \\
Baitussalam & 5,274 \\
\hline Central Statistics Agency (BPS) Aceh 2018
\end{tabular}

Based on Table 4.2 the number of households per subdistrict it is possible to see different numbers in each district based research locations in Aceh Besar district. So that the number of sampling and serve as the respondent about 1 percent of the number of households considered to be representative of the population.Community participation can be measured through the interactions and relationships between people who will be affected by this participation and its relation to the welfare of society. In Aceh Besar district it can be seen from their participation, but participation is illustrated very minimal and in fact most of the people do not understand very well the concept of Allocation Gampong (ADG), which is the process by which society is possible to be active and involved in ADG impact on people's lives and may even be one of the strategies for poverty reduction as well as the public is given the opportunity to take action to achieve change.

\subsection{Poverty Alleviation Efforts Through Increased Allocation Funds Absorption Gampong (ADG) In Villages In Aceh Besar district}

In 2015 it was noted that the number of people in Aceh Besar district is 392584 inhabitants, it can be estimated the population density reaches 135 inhabitants $/ \mathrm{km} 2$, and the population growth rate reached $4.02 \%$. In the same year the number of poor people can reach 62270 people, with a poverty line of Rp. 366676 per Kap / month and the level of $15.93 \%$ of poor people. Number of poor in Aceh Besar district from year to year has decreased relatively likely to satisfy. This can be seen in the following table (Table .3) 
Table 3. Poverty rates (Thousand People) in Aceh Besar district

\begin{tabular}{cc}
\hline Year & $\begin{array}{c}\text { Number of Poor People } \\
\text { (Thousand people) }\end{array}$ \\
\hline $\mathbf{2 0 1 4}$ & 62.37 \\
$\mathbf{2 0 1 5}$ & 62.27 \\
$\mathbf{2 0 1 6}$ & 62.03 \\
\hline : Central Statistics Agency (BPS) Aceh 2018
\end{tabular}

In 2016, the Central Government allocated gampong Village Fund or Funds amounting to 3.8 trillion for Aceh. This number has increased more than 100 percent, when compared to fiscal year 2015, only Rp 1.7 trillion. Government of Aceh Besar district village budget allocations from the central government in 2016 amounted to 350 billion. Funds division ADG and its use is governed in Aceh Besar Regent Regulation No. 3 of 2016. The efforts forward to support participatory development planning process should be more focused on capacity development at the system level, institutions and individuals to ensure continuity of innovation and concept development in the future come.

\subsection{Increased Public Participation To Increase Allocation Funds Absorption Gampong (ADG) In Poverty In Villages in the district of Aceh Besar}

Based on the above analysis, it can be formulated in the form of a strategy to improve community participation to improve the absorption of ADG so as to reduce poverty in rural villages in Aceh Besar district. Qanun in Aceh Besar Regent in the form of regulations on Procedures for the Management and Allocation of Funds Allocation Gampong in Aceh Besar district, governed by very clear in article 12 of the third section of the Use of ADG. So that these regulations are considered inflexible to the public, so that the entire allocation of funds is only absorbed into the use of funds ADG has been set by local governments. The key point in increasing public participation is to determine the level of participation. There are several approaches that can be used are: 1) Information, 2) Consultatio, 3) Deciding Together, 4) Acting Together, 5) Supporting independent community interest,

Berdasarkan several approaches, in this study the Village Fund Allocation (ADG) in Aceh Besar district as a whole only meets the Information approach. It can be seen from the results of research in the field where public participation in ADG merely getting information from the device gaampong about ADG. Efforts forward to support participatory development planning process should be more focused on capacity development at the system level, institutions and individuals to ensure continuity of innovation and concept development in the future. Here the number of poor households in Aceh Besar District based on the Integrated Data Base (BDT) in 2015 according to the districts sampled in this study, can be seen in figure 4.1 below: 




Basis Data Integration for Social Protection Program administered by the National Team to Accelerate Poverty (TNP2K) is a system that can be used for program planning and identify the names and addresses of recipients of social assistance, whether households, families and individuals based on criteria of social executive-economic set by the Program.

\section{Conclusions}

Qanun in Aceh Besar Regent in the form of regulations on Procedures for the Management and Allocation of Funds Allocation Gampong in Aceh Besar district, governed by very clear in article 12 of the third section of the Use of ADG. Therefore it can be concluded actors involved in the participation of ADG only use the apparatus village level, while the community does not serve as a supporting actor in ADG management participation. Flexible allocation of funds is not specified in the Qanun, short implementation time, and actors who are dominated by the village government officials to make the level of community participation in the program is very low ADG. ADG Budget usage should be regulated by the village authorities and communities for a common cause. Thus, in the use of the ADG is expected not entirely spent on gampung only. Infrastructure development is expected to be improved so that the impact on society is also evident. So the purpose of clearly defined ADGlaws can be realized. Gampong independent and able to manage optimally utilizing different potentials such as: human resources, natural resources, the buyer (the market) as well as institutional and local culture.

\section{References}

[1] H. Nugroho, Poverty, Inequality, and Inequality. Yogyakarta: Aditya Media, 2015.

[2] Arikunto, S. 2010. Procedure Research: A Practical Approach. (Revised Edition). Jakarta: Rineka Reserved

[3] Body Bureau of Statistics. (2017).Aceh Besar in Figures 2016, Province. 
[5] (2015). Aceh Besar in Figures 2014. Aceh province.

[6] Gunawan Sumodiningrat. 2006. Empowering Communities. Jakarta: Penakencana Nusadwipa.

[7] Nasution. 2007. Methods Research: Scientific Research. Jakarta, PT. Earth Literacy.

[8] Ndraha, Taliziduhu. 2011. Dimensions Village Government. Jakarta: PT. BinaAksara..

[9] Government of Aceh Besar district. 2008. Regulation of the Regent of Aceh Besar No. 04 Year 2008 on the Financial Gampong. Regional News Year 2008 Aceh Besar District No. 04. Regional Secretary. Aceh Besar district

2016. Regulation of Aceh Besar Regent 32016 on the Procedures for Management of Funds allocator Gampong in Aceh Besar District Regional News Year 2016 Year 2016 Aceh Besar District Number: 03. Regional Secretary. Aceh Besar district . 2017. Regulation of Aceh Besar Regent 38 Year 2017 on the Procedures for Management of Funds allocator Gampong in Aceh Besar District Regional News Year 2016 Year 2017 Aceh Besar District No. 38. Regional Secretary. Aceh Besar district 2018. Regulation of Aceh Besar Regent 32018 on the Procedures for Management of Funds allocator Gampong in Aceh Besar District Regional News Year 2016 Year 2017 Aceh Besar District No. 38. Regional Secretary. Aceh Besar district

[13] Sutrisno, L. 2015. Towards a Participatory. Canisius, Yogyakarta

[14] Sufitrayati \& Fanny Nailufar. 2017. Community Participation Enhancement Strategies to Increase Allocation Funds Absorption Gampong in Poverty in Aceh Besar district. Grant PKPT University Veranda of Mecca.

[15] Sumiati. Village Allocation Funds Management, 2015. In the village of KecamatanSigi Biromaru Ngatabaru Sigi. E-journals Katalogis. Volume 3. No. 2. Page 135142.

[16] Suwandi, Ari Warokka. 2013. Fiscal decentralization and local special autonomy: Evidence from an emerging market. Journal of Southeast Asian Research. Vol.3 No. 4, IBIMA Publishing.

[17] Saputra, IW (2016). Village Allocation Funds Management Effectiveness at Lembean village of Kintamani, Bangli Regency Year 2009-2014. Development journal

[18] Thomas. 2013. Management of the village fund allocation in order to increase development in rural sub-district sebawang Sesayap Tana Tidung. eJournal Integrative Governance, 1 (1): 51-64. 